\title{
Convergence and polarization in global income levels: a review of recent results on the role of international technology diffusion
}

\author{
Guan Gong a , Wolfgang Keller ${ }^{\mathrm{a}, \mathrm{b}, \mathrm{c}, \mathrm{d}, *}$ \\ ${ }^{a}$ University of Texas, Austin, TX, USA \\ b Economics Department, Brown University, Box B, 64 Waterman Street, Providence, RI 02912, USA \\ ${ }^{\mathrm{c}}$ National Bureau of Economic Research (NBER) Summer Institute, Cambridge, MA, UK \\ ${ }^{\mathrm{d}}$ Center for Economic and Policy Research (CEPR), London, UK
}

Received 25 October 2001; received in revised form 20 August 2002; accepted 11 September 2002

\begin{abstract}
We review the recent literature on technological change and diffusion to shed new light on the evolution of the world's cross-country income distribution. Technology is viewed as non-rival knowledge in the sense that firms in more than one country can simultaneously use it. $R \& D$ investments generate often also a return outside the innovating firm itself; these knowledge externalities are called technology spillovers. We emphasize that technology is to some extent tacit, and technology diffusion often involves the face-to-face interaction of people. Our paper reviews the evidence on whether international trade, foreign direct investment, and other cross-border activities are important for technology diffusion.
\end{abstract}

() 2002 Elsevier Science B.V. All rights reserved.

Keywords: Technology spillovers; Tacit knowledge; Foreign direct investment; Trade; Communications

\section{Introduction}

Technology is important in explaining income levels across countries. The accumulation of physical and human capital matters as well, but that cannot explain much of today's cross-country incomes differences (Easterly and Levine, 2001; Prescott, 1998). If the rate of technical change differs across countries, this affects the world's distribution of income. New information and communication technologies (ICTs) have been developed relatively fast in the United States (US), for example, and this might help explaining why the US lead in per-capita income over Japan

\footnotetext{
* Corresponding author. Tel.: +1-401-863-9030; fax: +1-401-863-1970.

E-mail address: wolfgang_keller@brown.edu (W. Keller).
}

has increased from $10 \%$ in 1990 to $20 \%$ by 1999 (Economist, 2000; McKinsey, 2000).

Recent work has shown, however, that the major sources of technical change leading to productivity growth in OECD countries are not domestic; instead, they lie abroad (Eaton and Kortum, 1999; Keller, 2002a). ${ }^{1}$ The international diffusion of technology is therefore a major determinant of per-capita income in the world. Because most developing countries spend relatively less on basic science and innovationsformal R\&D spending, for instance, is highly concentrated in a handful of OECD countries-poorer countries rely even more on foreign sources of productivity growth than OECD countries do.

\footnotetext{
${ }^{1}$ Eaton and Kortum (1999) estimate for example that foreign research accounts for $87 \%$ of productivity growth in France (Table 5). See Section 3 for further results.
} 
This means that convergence in income turns on the degree of international technology diffusion. Strong diffusion is a force towards convergence, because it equalizes differences in technology across countries. Conversely, the absence of international technology diffusion favors divergence. Technical change in the presence of non-uniform international technology diffusion is at the heart of the recent "digital divide" discussion, for example, the widespread fear that the development of the Internet might not lead to convergence, but instead to a further polarization of the world's income distribution.

While it has been recognized since the classic 'Solow residual' paper (Solow, 1957) that rates of factor accumulation do not account for the major part of economic growth, the view that technological change has both domestic and foreign sources is less common. Arguably, the rapidly rising level of economic integration in the late 20th century, fostered by advances in transportation as well as in information and communication technology, makes the exclusive focus on domestic technological change obsolete. Sometimes the reason for productivity increases does indeed lie in purely domestic activities, such as the learning effects resulting from cumulative production for domestic demand. However, productivity also increases due to learning through the interaction between foreign and domestic firms. The greater importance of technology adoption from abroad-versus domestic technical change-in less developed compared with more developed countries suggests that learning through international economic activity might be particularly important for less developed countries.

This paper takes a look at the evidence to expand on these ideas. In the next section, we discuss the concept of international technology diffusion. We also provide some references to the underlying theories; the sections that follow are first and foremost a review of recent empirical work. Basic results on international technology diffusion are discussed in Section 3. Section 4 is devoted to international trade, foreign direct investment, and other channels of diffusion. In Section 5, we review the evidence on the heterogeneity of diffusion across products and industries. Section 6 discusses findings on the geographic localization of international technology diffusion, and Section 7 examines how this has changed over time. In Section 8, we discuss some evidence on major country-specific determinants for successful international technology diffusion. Finally, Section 9 summarizes the major findings, suggests directions for future research, and discusses policy implications.

\section{Conceptual issues}

\subsection{International technology diffusion in this paper}

It is central to much of the recent work to view technology as knowledge, as emphasized in the theories of endogenous technical change that emerged about 10 years ago (Aghion and Howitt, 1992; Grossman and Helpman, 1991; Romer, 1990; Segerstrom et al., 1990). ${ }^{2}$ In this framework, technology has three major characteristics. $^{3}$

1. Technology is non-rival in the sense that the marginal costs for an additional firm or individual to use the technology are negligible.

2. The return to investments towards new technology are partly private and partly public.

3. Technological change is the outcome of activities by private agents who intentionally devote resources towards the invention of new products and processes.

Out of these, points 1 and 2 are key for our purposes. The first characteristic means that technological knowledge can serve users beyond those who are currently employing it without raising the costs to the original set of users. Other authors have coined the terms 'perfectly expansible' (David, 1992) and 'infinitely expansible' (Quah, 2001a,b) to

\footnotetext{
${ }^{2}$ See Grossman and Helpman (1995) and Aghion and Howitt (1998) for broader overviews. I will also discuss some related work on learning-by-doing and human capital accumulation, as emphasized by Lucas $(1993,1988)$, that falls into the broad category of models of knowledge accumulation.

${ }^{3}$ See Romer (1990). Many of these ideas have been discussed in the literature before; important contributors include Paul David, Giovanni Dosi, Robert Evenson, Jan Fagerberg, Richard Nelson, Keith Pavitt, Nathan Rosenberg, Luc Soete, Sidney Winter, Larry Westphal, and others (see Fagerberg, 1994 and Evenson and Westphal, 1995 for overviews). What distinguishes the recent work is that it includes fully specified general equilibrium models. This means that these technology effects can in principle be simulated and estimated in a well-defined framework.
} 
positively define this characteristic. It distinguishes knowledge from rival factor inputs such as human and physical capital; the latter can only be used by one firm at a time, or put differently, the marginal costs to use the same factor for a second firm are infinite.

The partially private, partially public nature of the return to technological investments implies that while there is a force that might be strong enough to sustain the private incentive to innovate (the private return, which is often a temporary monopoly secured by a patent), technological investments may also create benefits to firms and individuals external to the inventor by adding to their knowledge base (the public return). These benefits are usually called knowledge spillovers. An example is that the design of a new product might speed up the invention of a competing product, because the second inventor can learn from the first by carefully studying the product, or even the production design.

One contribution of these theories of technical change is that they have supplied improved micro foundations for thinking about knowledge spillovers. This survey of international technology diffusion is largely an analysis of the empirical literature of international technology spillovers and their effects on productivity. We do not attempt to provide a general review of the models of technology diffusion here, which is beyond the scope of our paper. ${ }^{4}$

Two basic mechanisms for international economic activities to lead to technology diffusion have been emphasized. ${ }^{5}$

(a) Direct learning about foreign technological knowledge.

(b) Employing specialized and advanced intermediate products that have been invented abroad.

Technological knowledge in this literature is typically the design, or blueprint, for a new intermediate product. Direct international learning about such technology means that a blueprint is known not only to a firm in the country where the blueprint was first

\footnotetext{
4 The interested reader is referred to the survey by Geroski (2000). For an introduction to the broader literature, see also Rosenberg (1976), David and Olsen (1992), Jaffe and Trajtenberg (1996), and Stoneman and Kwon (1994).

${ }^{5}$ See Rivera-Batiz and Romer (1991) for an exposition.
}

developed (or firms, if there are domestic spillovers), it also becomes known to firms in other countries. Such learning involves a positive externalityhence: spillover-if the technological knowledge is obtained at less than the original cost to the inventor.

The productivity of domestic invention is assumed to be increasing in a country's stock of knowledge, which itself is typically proportional to the number of domestically known product designs. This assumption captures the idea that creating a new product becomes easier as the number of already known product designs is larger. Thus, by adding to the domestic knowledge stock, international spillovers raise the productivity of domestic inventive activity. It might be called an active spillover, in the sense that the foreign blueprint becomes part of the domestic R\&D laboratories' stock of knowledge that can be actively used to invent new products.

According to point (b), technology diffuses internationally through foreign intermediate goods. The idea is that employing the foreign intermediate good involves the implicit usage of the design knowledge that was created with the R\&D investment of the foreign inventor. In this sense, the technological knowledge of the blueprint is embodied in the intermediate good. As long as the intermediate good costs less than its opportunity costs-which include the R\&D costs of product development - there is a gain from having access to foreign intermediate goods. This might be called a passive technology spillover: although an importing country has indirect access to the results of foreign $\mathrm{R} \& \mathrm{D}$, the technological knowledge embodied in the imported intermediate as such is not available to domestic inventors-only the manufactured outcome of it is.

What kind of international activities could lead to such active or passive spillovers? Clearly, the latter might be related to international trade and foreign direct investment (FDI) through intermediate goods imports and purchases from foreign-owned multinational subsidiaries, respectively. Employing the intermediate good that embodies technological knowledge is necessary for passive spillovers to occur. An implication of this is that the patterns of passive international technology spillovers might share certain characteristics of international trade and FDI. For instance, the volume of international trade between two countries 
is declining with bilateral geographic distance (see Leamer and Levinsohn, 1995). This suggests that to the extent that passive spillovers are important, international technology diffusion might have such a spatial structure as well.

There could also be interesting relations between active and passive spillovers. For instance, trade liberalization and market deregulation might have a significant impact upon technological knowledge generation and diffusion. ${ }^{6}$ Trade liberalization makes imported intermediated goods-say, machineryrelatively cheaper, which induces a reduction of the demand for possibly less advanced domestic intermediate goods and an expansion of imports of such goods. The substitution of imported for domestic machinery might affect other forms of knowledge in the domestic economy. Just as older vintages of locally produced machinery are rendered obsolete by importing newer and more efficient machinery goods, so, too, do certain forms of human capital lose their value. For example, the 'in house' engineers who were previously employed to extend the economic lifetime of the domestic machinery goods in a world in which newer foreign machines were difficult or impossible to obtain are now becoming redundant because their skills are embodied in the more advanced imported machinery equipment goods. This could relax some of the technical skill constraints that slow down the economic development of many less developed countries. At the same time, the adoption of the more advanced foreign technologies requires a new set of operational and maintenance skills (Dahlman et al., 1987). As a result, importing advanced foreign technology does not imply that domestic skill accumulation becomes unnecessary, only that a different skill profile, with a more flexible labor force, is required. The substitution for domestic skilled labor through imports of intermediate goods might on net also lead to an increase in the ratio of passive ('embodied') technology spillovers relative to active technology spillovers. This can occur if the direct effect of importing embodied foreign technology on the incentives for domestic skill accumulation in form of human capital

\footnotetext{
${ }^{6}$ Detailed studies of the impact of trade liberalization policies in Latin American provide some evidence in support of this point. See e.g. Katz (2000) and Cimoli (2001).
}

is strongly negative, so that an economy has to rely increasingly on embodied technology from abroad.

With an increasing degree of 'commoditization' of goods and services, passive spillovers might become the dominant way for technology diffusions. For instance, there is some evidence showing that the importance of so-called "Internationally Integrated Production Systems" has increased significantly as a percentage of GDP during the course of the 1990s throughout Latin America (Cimoli and Katz, 2001). For example, when Ford launched its Ford Taurus model in Argentina in 1974, this required some $300,000 \mathrm{~h}$ of domestic engineering efforts over one and a half years to adapt the German-designed blue prints to the local production conditions. The domestic content for such car was about to $90 \%$ of the total value of the vehicle, and nearly 400 subcontractors supplied parts and components. With the commoditization of automobiles, this localized technological regime with a large active spillover potential is gone. Today Ford Argentina is part of a world wide integrated production system, and its operation is strongly based on imported parts and components. The local content of production dropped to less than $50 \%$. Although the productivity gap between the Argentine automobile industry and the world frontier has been somewhat shrinking over time, the process in which local operations have increasingly turned into assembly activities might lead to an increasing isolation of peripheral countries from the places in the world where technology is generated.

In contrast to passive spillovers, the purchase of intermediate goods is neither necessary nor sufficient for spillovers of the active kind. The technological knowledge that allows the inventor to produce a new product (or operate a new process) is often summarized in a production plan, or blueprint. Typically, this is now stored in electronic format, say, on a computer diskette. This blueprint is non-rival, or, infinitely expansible, in the above sense. What governs the access to this technological knowledge, or, put differently, what are the major determinants of active international technology spillovers? There might be legal constraints such as patents that allow the owner to exclude others from using the blueprint knowledge. ${ }^{7}$ If the focus is on technological feasibility, however, the

\footnotetext{
${ }^{7}$ Indeed, in most standard models, it is assumed that the knowledge is patent-protected.
} 
knowledge codified in the blueprint can diffuse in any way and pattern in which a file on a computer disk can be distributed. And since the late 20th century, it can be sent at very low cost over computer networks to even remote places in the world.

Should one therefore expect that active technology spillovers are, in the absence of legal constraints, global? Not necessarily. Consider first that from the point of view of the inventor, the leaking out of knowledge to others is the opposite of what he or she is interested in. Unless there is an explicit technology licensing contract, the inventor has the incentive of keeping the knowledge secret. If international economic relations involve person-to-person contacts of people who have the technological knowledge and others who do not, this could make it more difficult for the inventor to prevent knowledge spillovers from occurring. From the point of view of the learner, international contacts make it easier to copy foreign technologies. At a broader level, international activity such as importing, exporting, or FDI might also help to establish and sustain channels of communication that stimulate cross-border learning of production methods, product design, organizational methods, consumer preferences, and market conditions. ${ }^{8}$ The process of technology transfer that is described by product-cycle models is a good example of such learning effects (Vernon, 1966; Grossman and Helpman, 1991).

These considerations are strengthened when one explicitly recognizes the fact that the view of technological knowledge that is limited to codified knowledge is too narrow. In addition to the information that is codified in the blueprint, there is other information that must be acquired if the technological knowledge is to be utilized effectively. Many careful studies of technology and how it is transferred conclude that only the broad outlines of technological knowledge are codified-the remainder remains 'tacit' (Polanyi, 1958). ${ }^{9}$ In Polanyi's view, knowledge is to some extent tacit because the person who is actively engaged in a problem-solving activity cannot necessarily de-

\footnotetext{
${ }^{8}$ It might also be possible to acquire the technological knowledge embodied in an intermediate good by taking it apart and reverse-engineering it. This would require importing one unit of a particular good, but not a substantial quantity of them.

9 The following draws also on Arrow (1969), David (1992), Evenson and Westphal (1995), Teece (1977), von Hippel (1994), and references given there.
}

fine (and hence prescribe) what exactly he or she is doing. In this view, technological knowledge is only partially codified because it is impossible or at least very costly to do so.

Teece (1977), for instance, finds that the non-codified part of the costs of transferring technology between plants is substantial. In his sample of 26 projects, he estimates that the costs of the transfer were on average almost $20 \%$ of the total project costs. ${ }^{10}$ It is of course possible to convert tacit to codified knowledge (software expert systems do just that), and the costs of doing this has fallen in some areas over recent years. However, also more recent analysis has shown that non-codified knowledge continues to be important for understanding patterns in the creation and diffusion of knowledge (von Hippel, 1994).

What are the implications of non-codified knowledge for the role of international economic activity in technology diffusion? Polanyi (1958, p. 53) argues that tacit knowledge can be passed on only "by example from master to apprentice". A broader view is that non-codified knowledge is usually transferred through demonstrations, through personal instructions, as well as through the provision of expert services (David, 1992, p. 221). In general, if knowledge is partly non-codified, then person-to-person communication becomes relatively more important for the diffusion of knowledge.

No doubt, the quality of communication between persons at different locations has dramatically improved recently. However, person-to-person communication means often still face-to-face communication. Together with the fact that it is costly for people to move in geographic space, this suggests that the higher is the relative importance of non-codified knowledge, the more are technology creation and dif-

\footnotetext{
${ }^{10}$ For transferring machinery equipment technology, this share was $36 \%$ (Teece, 1977, p. 248). Teece's estimates are a lower bound for technology transfer to less developed countries, as his sample includes to two-thirds relatively advanced countries. He lists the following types of costs (245-246): pre-engineering of technological exchanges, costs associated with transferring the process/product design and the associated engineering, $R \& D$ personnel costs during the transfer phase, pre-start-up training and excess manufacturing costs. Teece also shows suggestive evidence on when these costs are particularly high or low, for instance in relation to similar production experience (-) or general level of development (-).
} 
fusion geographically centralized. ${ }^{11}$ Further, engaging in international economic activity such as trade or FDI is invariably accompanied by communication, not infrequently in form of face-to-face contacts. From this perspective of partially-codified knowledge, it appears that not only passive spilloversembodied technology in intermediate goods-but also active spillovers are linked to the patterns of international economic activity, instead of being uniformly distributed (or distributable) throughout the world. ${ }^{12}$

\subsection{Alternative views on technological knowledge and its diffusion}

Alternative views include Mankiw (1995) and Parente and Prescott (2000) who think of technological knowledge as a global pool of knowledge, available to firms and individuals in all countries. Their explanations for differences in per-capita income across countries differ. In Mankiw's view, the explanation lies in differences in complementary fac-

\footnotetext{
${ }^{11}$ Evidence supporting this view is provided in von Hippel (1994) and Feldman and Lichtenberg (1997). The former finds that when technological knowledge is non-codified, the problem-solving activity must often be located on-site-it cannot be done effectively from a distance. Von Hippel also finds that when knowledge is non-codified in different locations, optimal business strategy typically implies to adopt a sequential and iterative, not simultaneous, pattern of problem-solving. Feldman and Lichtenberg (1997) construct measures of tacitness of knowledge for their study of $R \& D$ activities in the European Union. They find that the more tacit knowledge is, the more centrally located are the R\&D activities.

12 Note another distinction frequently made in the literature on spillovers, that between rent and knowledge spillovers (e.g. Griliches, 1995). The former are productivity spillovers only in a measurement sense, because they occur solely because, for example in computing the productivity of the intermediate good-using industry, one does not properly take account of the high quality of the intermediate good. This leads to an overestimate of the productivity of the intermediate-using industry. Major reasons for that are unavailable, or slowly adjusted price indices. By contrast, knowledge spillovers are 'true' spillovers in the sense that they involve a positive externality. In practice, it has been difficult to separate these two types of spillovers empirically. Because passive spillovers as characterized above involve the purchase of goods, they might involve often an element of rent spillovers. Productivity calculations are also complicated by the need to do this in a way that accounts for new goods (see Feenstra et al., 1994).
}

tor accumulation, especially of physical and human capital. ${ }^{13}$ Recent analysis suggests that this hypothesis is difficult to maintain (Klenow and Rodriguez-Clare, 1997; Hall and Jones, 1999). Instead, a large part of cross-country differences in income per-capita have to do with total factor productivity (TFP). ${ }^{14}$

In Parente and Prescott (2000) view, even though technological knowledge is global, productivity differences are not primarily explained by differences in the availability of rival factors. Instead, the main cause of cross-country productivity differences is that there exist differences in the actually employed technological knowledge. According to Parente and Prescott, this results in turn from cross-country differences in the countries' resistance to adopt the world's frontier technological knowledge.

This emphasis on policy differences resulting from different political-economy equilibria is a priori plausible. At the same time, while policy differences play a certain role, it seems at this point ambitious to show that policy differences are the central reason for cross-country TFP differences. There are plenty of instances where linking TFP differences to the activities of lobbies, state bureaucracies, or self-interested politicians is not obvious. More empirical work is needed that identifies the resistance-to-new-technology factor and shows that it has major productivity effects at the macro-level. ${ }^{15}$ Moreover, if technological knowledge is global and countries differ in their resistance to adopt it, then TFP is country-specific, and bilateral or spatial characteristics should play no role for the distribution of technological knowledge in the world.

\footnotetext{
13 It often involves noting that rich countries have higher-quality capital than poorer countries. Differences in technological knowledge are thereby subsumed into differences in the quality of capital goods. For example, Mankiw (1995, p. 281) argues that countries share the same production function, but "when an economy doubles its capital stock, it does not give each worker twice as many shovels. Instead, it replaces shovels with bulldozers". Following this line of argument leads to an analysis of growth from an accounting perspective. It is not very helpful, though, for explaining the fundamental causes of growth and income differences. See also Romer (1992).

${ }^{14}$ See also Prescott (1998) and Easterly and Levine (2001), as well as other contributions at the recent World Bank conference on cross-country growth regressions, at http://www.worldbank.org/ research/growth/regressions.htm.

15 The debate surrounding Olson (1982) thesis might be instructive as well.
} 
This implication conflicts with the evidence that are discussed in Section 6.

In a set of papers, Quah has discussed characteristics that might characterize the knowledge-driven, or 'weightless' economy (e.g. Quah, 2001a,b). In his framework, technological knowledge is disembodied, codified, and global, whereas human capital is embodied, tacit, and local knowledge. This might be a good starting point to further study international technology diffusion. Instead, Quah's main interest is to analyze how certain infinitely expansible product innovations such as computer software, video entertainment, and genetic databases might lead to a process of technical change that is much more influenced by consumers (or, demand) than previously, and less so by entrepreneurs (or, supply).

A more substantial departure from neoclassical explanations on technological change and its diffusion is the evolutionary approach especially as laid out by Nelson and Winter (1982). We cannot do justice here to the large literature in this area. ${ }^{16}$ Instead, we simply want to emphasize some points that are particularly important in the present context. Differently from the neoclassical perspectives of technology as "blueprint" or "designs" that can be traded on markets, evolutionary theory portrays technology, or know-how to do things, as organizationally embedded. The process of innovation is thus based on the joint activities of many actors within organizations and environments. Country-specific factors are thought to affect the process of technological diffusion through various channels. The concept of a "national innovation system" (NIS), developed by Lundvall (1992) and Nelson (1993), is used as an analytic device to examine countries with a system-theoretic approach. A basic assumption underlying the NIS approach is that innovation capabilities of firms are in a sense national, and can be enhanced by national policies.

Before turning to the discussion of empirical results on international technology diffusion, we highlight in the following that not all growth effects that have been discussed in this context have to do with international technology diffusion.

\footnotetext{
$\overline{16}$ See Witt (1993), Dosi and Nelson (1994), as well as Nelson and Winter (2002) for introductions.
}

\subsection{Growth effects that are not related to international technology diffusion}

The degree of international economic activity, from the one extreme of autarky to the other of full integration, can have important implications for a country's productivity through mechanisms other than international technology spillovers. Among the important ones are give I the following sections. ${ }^{17}$

\subsubsection{Trade and domestic monopoly}

The liberalization of international trade might reduce the monopoly power of domestic firms, thereby affecting pricing behavior and the efficiency with which domestic resources are utilized (Tybout, 2000 discusses the evidence). Clearly, this effect is not related to technological knowledge diffusion from abroad. ${ }^{18}$

\subsubsection{Trade and knowledge accumulation through learning-by-doing}

If trade liberalization triggers changes in the domestic resource allocation, this might lead to changes in a country's growth rate. Young (1991) for instance develops a model with two countries, north and south, that each produces a range of products. A country's growth rate is determined by the prevailing level of learning-by-doing, which is the cost-lowering effect from cumulative production. The potential for learning-by-doing is high for more recently invented products while for older products, learning-by-doing effects are exhausted. Young shows that trade liberalization might slow down the rate of growth in the south relative to autarky. This happens if the north has a comparative advantage in newly invented products so that trade liberalization leads to a specialization in the south on goods in which learning-by-doing is exhausted.

\subsubsection{Trade and endogenous technical change}

Grossman and Helpman (1991, Chapter 6) show that such results can be obtained also in models of en-

\footnotetext{
${ }^{17}$ For simplicity, the focus here is on international trade, but analogous arguments apply as well to FDI and other forms of international economic activity.

18 Instead, this mechanism is similar to the "non-technological" and "policy" determinants of TFP that are emphasized in Solow (2001) and Klenow (2001), respectively; it is also related to Parente and Prescott (2000) main thesis.
} 
dogenous technical change. Assume that there are two final goods, $\mathrm{X}$ and $\mathrm{Y}$, produced with varying factor intensity, plus an R\&D activity that produces inputs for the $\mathrm{X}$ good. Productivity growth is related to $\mathrm{X}$ production, because analogous to the static model of Ethier (1982), an increasing set of specialized intermediate inputs allows the production of more output with the same amount of inputs. In this situation, the growth effects of trade liberalization depend on whether it raises or lowers the relative price of good $\mathrm{Y}$ (that is, it again depends on comparative advantage). If trade liberalization raises it, resources move out of $\mathrm{X}$ production (and the $\mathrm{R} \& \mathrm{D}$ laboratories) and into the $\mathrm{Y}$ sector. As a consequence, growth slows down relative to before. The opposite occurs if trade liberalization lowers the relative price of good Y.

Trade liberalization might have important growth effects through changes in the domestic resource allocation, although we are not aware of much evidence that shows this to be the case (see also the overview in Tybout, 2000, pp. 37-38). It is worth emphasizing, though, that these particular models do not involve the international diffusion of technology. This is clear from the fact that it is possible to find a tax and subsidy policy that affects the domestic resource allocation in just the same way as trade liberalization does, and which therefore has the same growth effects. ${ }^{19}$ These models highlight the fact that there might be growth effects from trade liberalization that are not related to international technology diffusion. Arguably, one might expect the diffusion effects associated with international trade to be of dominant importance, at least for less developed countries. We will discuss the available evidence later. In any case, insofar as what diffuses is additional knowledge, it is difficult to see how this could lower a country's growth rate and welfare relative to autarky: access to more, rather than less, knowledge, just like more choices, should leave a country at least weakly better off.

\footnotetext{
19 The standard mechanisms of international technology diffusion are not present in either Grossman and Helpman's or Young's model. In the former model, neither are the specialized intermediate inputs internationally tradable, nor are there domestic learning effects from foreign R\&D. In the latter model, each country's stock of knowledge depends only on its range of production; there is no direct link between domestic and foreign stocks of knowledge. Moreover, the learning-by-doing stages that the north has passed through are not transferable: they have to be repeated by the south.
}

We now turn to discussing basic results on the international diffusion of technology.

\section{International technology diffusion: basic magnitudes}

A number of different approaches have been employed to study empirically the importance of international technology diffusion. The first and largest set of papers consists of so-called international R\&D spillover regressions. ${ }^{20}$ This literature studies the productivity effects of foreign $R \& D$ on domestic productivity. It is analogous to the literature that has examined the effects of other firms' $R \& D$ on a given firm's productivity in a closed economy (Griliches, 1979, 1995; Scherer, 1984). Typically, a production function approach is used to relate TFP to measures of domestic $(R)$ and foreign R\&D $(S)$ activities $^{21}$

$\ln \mathrm{TFP}_{c t}=\alpha_{c}+\alpha_{t}+\beta_{r} \ln R_{c t}+\beta_{s} \ln S_{c t}+\varepsilon_{c t}$,

where $c$ indexes country and $t$ subscripts time; $\alpha_{c}$ and $\alpha_{t}$ make for a generalized and time-varying intercept, and $\varepsilon_{c t}$ is an error term. The definition of $S$, the term capturing the impact of foreign $\mathrm{R} \& \mathrm{D}$, is typically given by a weighted sum of other countries' $R \& D$ :

$S_{c t}=\sum_{h \neq c} \omega_{c h t} S_{h t}$,

where $\omega_{c h t}$ is a bilateral weight that captures the relative importance of R\&D in country $h$ for productivity in country $c$. In the earlier literature on inter-industry technology diffusion in a given country, the $\omega$ are often input-output shares. More recent studies of international R\&D spillovers, for example, by Mohnen (1992) and Coe and Helpman (1995), have employed import shares as weights. Depending on the particular channel of technology diffusion that authors analyze, also FDI or other weights have been employed (see Section 4).

These regressions are partial-equilibrium in nature, and the R\&D expenditures, as well as the weights ù, are often endogenous. In addition, omitted variables might be causing biases. The work in this literature

\footnotetext{
${ }^{20}$ See Mohnen (2001) for a recent survey.

${ }^{21}$ For a discussion of TFP as an indicator of technical change, see Hulten (2001).
} 
varies in the extent to which the authors address these potential problems. At its best, this approach provides useful information on the long-run average relationship between $R \& D$ and productivity in a reduced-form framework.

The importance of international technology diffusion can be calculated in a number of ways. One approach is to compare the TFP elasticities of domestic and foreign R\&D. Coe and Helpman (1995) estimate for their sample of 22 industrialized countries a domestic R\&D elasticity of about $8 \%$ for the 15 smaller countries, and $23 \%$ for the G-7 countries. $^{22}$ The corresponding elasticities with respect to foreign R\&D are about 12 and 6\%, respectively. Thus, for the 15 smaller countries, the effect from foreign $R \& D$ is larger than that from domestic R\&D, with a factor of about 1.5. The share of about $20 \%$ for foreign $R \& D$ in the total elasticity effect for the G-7 countries is similar to Keller (2002b) estimate in his analysis of the G-7 countries plus Sweden using data at the industry-level. By contrast, Park (1995) in his analysis of aggregate data for ten OECD countries (including the G-7) estimates that foreign $R \& D$ accounts for about two thirds of the total effect of $R \& D$ on productivity (domestic R\&D elasticity of $7 \%$, foreign $R \& D$ elasticity of $17 \%)$.

In a series of papers, Eaton and Kortum (1997, 1999) and Eaton et al. (1998) have developed general equilibrium models in which productivity growth is related to increases in the quality of intermediate goods. ${ }^{23}$ As is often the case in empirical work based on a structural model, in order to arrive at a framework that can be estimated, Eaton and Kortum have to make some strong assumptions. For instance, the quality of technological knowledge that is discovered in a country in Eaton and Kortum (1999) is a random variable with a Pareto distribution, while the distribution of the time until it has diffused to other countries is exponential. Assumptions such as these are difficult to test in the context of a given model. Eaton and Kortum's empirical results are thus better viewed as estimating or simulating a particular model, rather than selecting one model among several, or testing it.

\footnotetext{
22 These are Canada, France, Germany, Italy, Japan, the United Kingdom, and the United States.

${ }^{23}$ This is as in the 'quality-ladder' model of Aghion and Howitt (1992); see also Howitt (2000).
}

Eaton and Kortum's work shows that the pay-off to this can be high. Their framework allows not only studying the reduced-form relationship between $R \& D$ and productivity, but also the models' predictions for the transitional adjustment path to the long-run equilibrium (Eaton and Kortum, 1997). They also examine the effects of changes in economic policy (Eaton et al., 1998), and Eaton and Kortum (1999) model R\&D and the diffusion of knowledge together with the related activity of international patenting. With regard to the relative importance of technology diffusion from abroad, the latter paper presents results based on data for the G-5 countries around the year 1988. Eaton and Kortum estimate that the part of productivity growth that is due to domestic as opposed to foreign $\mathrm{R} \& \mathrm{D}$ is between 11 and $16 \%$ in Germany, France, and the UK; it is around 35\% for Japan, and about $60 \%$ for the United States (1999, Table 5).

The recent work by Keller (2001c, 2002a) represents a third approach. Unlike Eaton and Kortum's work based on general equilibrium models, Keller studies the relationship between productivity and foreign $R \& D$ in a single-equation, partial-equilibrium framework. And unlike the R\&D spillovers literature discussed above, Keller (2001c, 2002a) estimates the TFP effect of foreign R\&D jointly with the importance of one or more channels of diffusion for foreign $R \& D$. One can view this as estimating the weights $\omega$ of the foreign $R \& D$ variable together with the parameter â that measures the TFP elasticity. Estimating the weights instead of assuming particular weights that are taken from data tables means to impose less structure ex-ante. Given how little is known on international technology diffusion to date, this seems to be reasonable. Using this method, Keller (2002a) estimates that between 1983 and 1995, the contribution of technology diffusion from G-5 countries is on average almost $90 \%$ of the total R\&D effect on productivity in nine other OECD countries (Table 6). ${ }^{24}$

This shows that irrespective of which particular approach is taken, the results invariably point to a substantial contribution of foreign technological activity to domestic productivity. It also seems that the relative contribution of international technology diffusion to domestic productivity growth is inversely

\footnotetext{
${ }^{24}$ These are Australia, Canada, Denmark, Finland, Italy, The Netherlands, Norway, Spain, and Sweden.
} 
correlated with economic size and with the level of development. ${ }^{25}$

\section{Channels of technology diffusion}

Many authors have studied through which mechanisms, or channels, international technology diffusion primarily occurs. We first look at work that has considered international trade.

\subsection{Trade}

Coe and Helpman (1995) are the first to provide evidence on the importance of trade for international technology diffusion along the lines of recent theory. Using the spillover regressions framework shown on p. 17 with bilateral import shares as weights, these authors examine two predictions. First, Coe and Helpman (1995) study whether a country's productivity is increasing in the extent to which it imports from highas opposed to low-knowledge countries (an import composition effect). Second, for a given composition of imports, these authors analyze whether a country's productivity is higher, the higher is its overall import share. Coe and Helpman's regression results suggest that there is support for both predictions. The authors conclude that international R\&D spillovers are related to the composition of imports, and that the overall level of imports is important for international technology diffusion as well. Coe et al. (1997) find similar effects in their analysis of foreign technology diffusion from highly industrialized to 77 less developed countries. ${ }^{26}$

By contrast, Eaton and Kortum (1996) find that once distance and other influences are controlled for, bilateral imports do not help to predict bilateral patenting activity, the indicator of international technology diffusion in their model. Moreover, Keller (1998) repeats the Coe and Helpman (1995) regres-

\footnotetext{
25 This would be very important for less developed countries. Primarily due to the much greater difficulty in obtaining comparable and high-quality data for less developed countries, there is a relative paucity of results in this regard. See, however, Coe et al. (1997), Connolly (1998), and Mayer (2001), as well as the discussion later.

${ }^{26}$ Nadiri and Kim (1996) show results from estimating cost functions in OECD countries; their approach also uses the bilateral-imports weighted spillover variable.
}

sions with counterfactual 'import' shares. ${ }^{27}$ For there to be strong evidence for trade-related international R\&D spillovers, he argues, one should estimate a positive effect from foreign $R \& D$ when bilateral import shares are employed, but no strong effect when counterfactual 'import' shares are used. Keller finds similarly high coefficients and levels of explained variation when counterfactual instead of actual import shares are used. He concludes that, on the basis of their analysis, Coe and Helpman's claim cannot be upheld: the import composition of a country has not a strong influence on the regression results. ${ }^{28}$ Keller (1998) results have led some to doubt the importance of trade for international technology diffusion.

More recent work has strengthened the evidence for import-related international technology diffusion. Keller (1997b, 2000) has extended his analysis of estimating international R\&D spillovers with counterfactual data by moving to industry-level data for eight industrialized countries. His results suggest that import composition might not matter for technology diffusion if countries' import patterns are more or less symmetric, but they do matter if countries receive a relatively high share of its total imports from one particular country - such as is the case for Canada, for example, which imports about $80 \%$ from the United States. ${ }^{29}$

\footnotetext{
27 That is, instead of bilateral import shares, Keller (1998) uses counterfactual (or, made-up) shares in creating the foreign $R \& D$ variable $S$ (see p. 16).

${ }^{28}$ Keller (1997a) presents analogous results in the context of inter-industry technology flows.

${ }^{29}$ As Coe and Hoffmaister (1999) emphasize, Keller (1998) creates his counterfactual 'import' shares in a way that makes their variance across different simulations rather small, and values higher than 0.3 are essentially never obtained. Thus, his import shares are not fully random in that sense. This was first pointed out in 1996 by an anonymous referee at the European Economic Review to both Keller and the editor, Elhanan Helpman. Keller (1998) paper includes therefore results with the unweighted sum of foreign R\&D as well. These do not support the Coe and Helpman (1995) claim that international R\&D spillovers are related to the composition of imports either, which is Keller (1998) point (see his Table 2). In a different context, Keller (1997b, 2000) shows that certain randomizations of import shares lead to equally strong empirical results as those based on observed imports, while others do not. He also discusses the relationship between random import shares and unweighted sum-of-foreign-R\&D regressions. Coe and Hoffmaister (1999) show that for three types of randomizations of import shares, the Coe and Helpman (1995) framework does not lead to a finding of international R\&D spillovers. This means that the bilateral import shares have some power.
} 
Moreover, Xu and Wang (1999) show that the import composition effect is robust when one considers capital goods trade instead of all-manufacturing goods trade. $\mathrm{Xu}$ and Wang show that if the weights in the construction of the foreign R\&D variable $S$ are capital goods import shares, one obtains an $R^{2}$ of $77.1 \%$ versus $74.9 \%$ with Keller (1998) counterfactual shares, and $70.9 \%$ in Coe and Helpman (1995). Also Lumenga-Neso et al. (2001) have revisited the results of Coe and Helpman (1995) and Keller (1998). Instead of computing the foreign knowledge variable as a bilateral-import share weighted sum of foreign R\&D, Lumenga-Neso, Olarreaga, and Schiff construct an alternative variable that aims at taking account of previous rounds of imports as well. This captures the case that even if some country $c$ imports only from some other country $h$, for instance, the former might still gain access to technology from countries other than $h$-if country $h$ has in turn imported from those other countries before. Using this variable, Lumenga-Neso, Olarreaga, and Schiff find slightly stronger results than Keller (1998).

Other evidence on the importance of trade for international technology diffusion includes Sjöholm (1996), who examines citations in patent applications of Swedish firms to patents owned by inventors in other countries. Patent citations as indicator for knowledge flows have proven to be useful recently in a number of other studies (see Sections 6 and 9). Controlling for a number of other correlates and also conducting an extreme-bounds analysis, Sjöholm finds a positive correlation between Swedish patent citations and bilateral imports. This result is consistent with imports contributing to international knowledge spillovers.

Two recent papers by Eaton and Kortum (2001a,b) also focus on the importance of trade for the international diffusion of technology. The authors combine the structure of technology diffusion and growth in Eaton and Kortum (1999) with that of the Ricardian trade model due to Dornbusch et al. (1977). A country's productivity level is related to its implicit access to foreign technology through equipment good imports. Thus, their notion of technology diffusion is one of passive (embodied) technology diffusion. Transport costs that increase in geographic distance imply that productivity in remote countries is relatively low, ceteris paribus, or equivalently, the price of equipment goods is relatively high. Eaton and
Kortum (2001a) use this framework to predict, for example, that $25 \%$ of the cross-country productivity differences among 34 more-, as well as less-developed countries can be attributed to differences in the relative price of equipment. It would be interesting to see how international trade might at the same time increase the likelihood of active knowledge spillovers. This would also allow the estimation of the relative importance of active and passive spillovers for international technology diffusion.

The work discussed so far focuses on technology diffusion related to imports. Learning through exporting, however, might be important as well (e.g. Rhee et al., 1984). A number of recent studies, including Bernard and Jensen (1999)—using US dataand Clerides et al. (1998) —using data from Colombia, Mexico, and Morocco- have used micro data to see whether there is evidence for learning-through-exporting. While exporting firms tend to be more productive than non-exporters in the cross-section, neither paper finds robust evidence that past exporting experience (Granger-) causes improvements in performance once other differences across firms have been taken into account. Thus, the available evidence does not point to strong learning-through-exporting effects. ${ }^{30}$

\subsection{Other mechanisms}

\subsubsection{Foreign direct investment}

It is often argued that foreign direct investment (FDI) involves the transfer of knowledge from one country to another (see, e.g. the discussion in Carr et al., 2001), making it a potentially important vehicle for international technology diffusion. ${ }^{31}$

Lichtenberg and van Pottelsberghe de la Potterie (1996) have analyzed the importance of FDI for international technology diffusion in thirteen OECD countries with the same R\&D weighting approach that Coe and Helpman (1995) and Keller (1998) use for imports. Lichtenberg and van Pottelsberghe de la Potterie (1996) do not find significant effects from inward FDI. Baldwin et al. (1999) find some positive inward FDI spillover effects in their industry-level study, but overall, the results are mixed. To some

\footnotetext{
${ }^{30}$ For more details, see Tybout (2001).

31 Blomström and Kokko (1998) have recently surveyed a number of ways how FDI could lead to spillovers.
} 
extent, this might have to do with the fact that good data on bilateral FDI is available to a much lesser extent than for trade. Therefore, the two above studies employ data on FDI stocks that is derived from balance-of-payments accounts. However, good measures of multinational activity, such as subsidiary GDP, sales, or its number of employees, are related to FDI stocks derived from balance-of-payment data only with a considerable amount of error. ${ }^{32}$

$\mathrm{Xu}$ (2000) uses the Bureau of Economic Analysis's data on US multinational enterprise (MNE) activity to study the relationship between US outward FDI and productivity growth in the host country. His analysis covers total manufacturing between 1966 and 1994 for 40 countries, of which about half are more and half are less developed countries. Xu finds generally a positive correlation between productivity growth and the ratio of subsidiary value added to host country GDP. This effect is stronger and more robust in the more developed countries than in the less developed countries.

As the availability of micro data has become greater, the study of FDI spillovers has increasingly turned to it. Aitken and Harrison (1999) examine data on Venezuelan plants between 1976 and 1989. They estimate a negative relationship of increased FDI presence and TFP of domestic plants. This can be rationalized if the estimates pick up a combination of the knowledge spillover effect (which is non-negative) and competitiveness or other effects. It could also arise from multinationals being attracted to industries where domestic competitors are structurally weak, if the estimation fails to fully control for this simultaneity effect. In any case, the effects could be short-term responses; as Aitken and Harrison note, their analysis may fail to capture the long-run effects of FDI (p. 617)..$^{33}$

\footnotetext{
32 One important reason for this is that FDI does not necessarily involve net flows of capital, because the latter can be raised in local capital markets.

${ }^{33}$ FDI presence in Aitken and Harrison (1999) is measured as the share of employment of foreign-owned firms in total employment. This variable can change without a change in employment by foreign-owned firms. Aitken and Harrison report, however, that including foreign employment and domestic employment separately in the regression leads to similar results (p. 610). This point applies also to the studies by Girma and Wakelin (2001) and Haskel et al. (2001), discussed later. We have not seen a discussion of this point in the latter papers, so we assume that it does not alter the results there either.
}

Girma and Wakelin (2001) use micro-data from the UK Census of Production to study the effects of inward FDI in the United Kingdom. The authors focus on the electronics industry between 1980 and 1992. Girma and Wakelin (2001) test whether plant productivity growth is systematically correlated to the ratio of foreign-owned plants to all plants in a given four-digit industry (and also by foreign investor country). Other variables are FDI in a given geographic region within the UK, and FDI in a given two-digit industry. The first tests for intra-industry FDI spillovers, the second and third for FDI spillovers from geographic and technological proximity, respectively. The authors find a positive productivity effect from Japanese and Other foreign FDI, but not from US FDI. There is also evidence in support of FDI spillovers from technological proximity, but no evidence that within-region spillovers are stronger than those across regions. ${ }^{34}$

Haskel et al. (2001) use the same database, but add both more years and plants from all of manufacturing to the sample. They confirm the Girma and Wakelin (2001) findings that technological proximity seems to matter for FDI spillovers, whereas geographic proximity within the UK does not. Haskel et al. (2001) estimate positive spillovers from US and French FDI, whereas Japanese FDI is here negatively correlated with productivity growth. ${ }^{35}$ Even though they find

\footnotetext{
34 Jaffe et al. (1993) as well as Adams and Jaffe (1996) find evidence that distance matters for domestic technology diffusion. To be consistent with that, Girma and Wakelin's result might have to be interpreted as saying that conditional on technology coming from abroad, geographic distance within a country does not matter. See also Section 6.

35 The differences in results relative to Girma and Wakelin (2001) could be in part related to differences in the estimation technique. Girma and Wakelin favor a variant of the Olley and Pakes (1996) technique, whereas Haskel et al. (2001) employ a time differencing approach. The former method is conceptually more appealing, but it also requires making more specific assumptions that are difficult to test. Based on supplemental results for the Girma and Wakelin study using the time differencing method-provided to us by Sourafel Girma - one can compare their FDI spillover results using the modified Olley and Pakes technique with those based on time differencing. At a 5\% significance level, there are qualitative differences in 3 out of 10 of the key estimated coefficients in their Table 7. This does not settle the question of which estimates are closer to the true parameters. However, it suggests that to examine whether some of the assumptions in the Olley and Pakes framework can be tested or generalized is an interesting research project.
} 
partial evidence for statistically significant positive spillovers, Haskel, Pereira, and Slaughter's analysis of the economic benefit of these FDI spillovers for UK firms suggests that it was quite small compared to the subsidies that the UK government paid to attract these foreign-owned multinational firms.

Kinoshita (2000) presents firm-level evidence on the effects of inward FDI in the Czech Republic between 1995 and 1998. ${ }^{36}$ Unlike the other studies, Kinoshita has information on R\&D expenditures of the domestic firms, which might be an important omitted variable. At the same time, she has only a very short panel of data. In any case, controlling for R\&D, Kinoshita fails to find positive spillovers from inward FDI into the Czech Republic; however, there is a robust effect if the FDI variable is interacted with the firm's own $R \& D$ spending. A plausible interpretation of this is that the effects of international technology diffusion through FDI are conditional on a relatively high 'absorptive capacity' (Cohen and Levinthal, 1989), as measured by own R\&D investments. ${ }^{37}$

Globerman et al. (2000) analyze 220 patent applications by Swedish MNEs and non-MNEs in the year of 1986. These applications contain patent citations that the authors relate to both inward FDI from the cited countries as well as to outward FDI to the cited countries. Using a conditional logit estimation framework, Globerman et al. (2000) estimate a robust correlation between outward FDI and patent citationsnot only for MNEs, but also for non-MNEswhereas there is none on the inward side. Branstetter (2001a) analyzes a larger number of patent applications and patent citations between the US and Japan. ${ }^{38}$ While Branstetter (2001a) can measure FDI only by establishment counts, he can control for the firms' R\&D spending, which is a plus (see above).

\footnotetext{
36 The data comes from two surveys of the Czech Statistical Office. Because there is relatively little documentation on these so far, some caution is required in interpreting what follows.

${ }^{37}$ Haskel et al. (2001) find the FDI effects to be strongest for plants at the low- to medium-range of the distribution of skill intensities (skilled to unskilled workers); this seems to be not the plants with the highest absorptive capacity. Kinoshita (2000) also distinguishes FDI spillover effects for domestically-owned from those for foreign-owned firms, finding that only the former benefit. It would be interesting to see whether this also holds in the UK sample.

38 This is based on data for Japanese-owned FDI in the United States.
}

The data also allows him to distinguish product development subsidiaries - which presumably are relatively knowledge-intensive-from other subsidiaries. Branstetter finds that more FDI is associated with more patent citations, both from US firms to Japanese firms and vice versa.

\subsection{Communication patterns}

Some evidence has begun to emerge on the importance of communication for international technology diffusion. Recent innovations have improved the communication and monitoring abilities between geographically distant plants, which has made it easier to outsource certain stages of production. This suggests that communication between geographically distant persons might also play a more important role today than it used to. At the same time, this does not necessarily mean that person-to-person communication patterns have become aspatial, for at least two reasons. First, remote communication might only be an imperfect substitute for face-to-face communication, and this point is reinforced if knowledge is to some extent tacit. Second, communication is to some extent spatial as long as international trade is, because trade requires some communication to develop in the first place. Moreover, more communication is also the consequence of international trade. Analogous arguments apply to FDI and other international economic activities.

Keller (2001c, 2002a) uses the imperfect proxy of bilateral language skills in the population at large to examine the importance of communication patterns for international technology diffusion among OECD countries. His results suggest that differences in communication patterns might have quite strong effects. For instance, if the share of English speakers in Spain (at 17\%) would rise to the level of the share of English speakers in The Netherlands (at 77\%), Keller (2002a) estimates that for Spain, this would be equivalent to a $15 \%$ boost of technology diffusion from English-speaking countries. ${ }^{39}$

\footnotetext{
39 A number of other channels of technology diffusion have been emphasized, but we are not aware of much recent empirical work along these lines. According to one argument, a country's outward FDI might facilitate technology learning in the FDI sending country. For instance, the FDI by Asian companies in the Silicon
} 


\subsection{Simultaneous analysis of multiple-channels of technology diffusion}

Although a few recent studies have considered several channels of technology diffusion simultaneously, the majority of them still examines only one channel in isolation. ${ }^{40}$ As documented by Kraay et al. (2001), firms do not typically engage in one type of international activity by itself; rather, they are engaged in several of them. Kraay, Isoalaga, and Tybout use information on whether a firm is (i) importing intermediate goods, (ii) exporting, or (iii) foreign-owned, as well as combinations of these. As in Clerides et al. (1998), the data comes from three panels of firms in Morocco, Mexico, and Colombia. Kraay, Isoalaga, and Tybout find no significant effects of international economic interactions on the firm's marginal cost or the quality of the good that it produces. By contrast, Keller (2001c)'s industry-level analysis of spillovers among the G-7 countries finds significant effects for imports, inward FDI, as well as communication links. In a breakdown of the total effect, he attributes more than $50 \%$ of the total effect to imports, and the remainder to equal parts to FDI and communication links.

\section{Heterogeneity and inter-industry effects}

R\&D spending is highly concentrated by industry. Among OECD countries, for instance, Keller (2002a) reports that about $80 \%$ of all manufacturing $\mathrm{R} \& \mathrm{D}$ is conducted in four three-digit ISIC industries: chemical products (including drugs), electrical and non-electrical machinery (including computers and telecommunication equipment), and transporta-

\footnotetext{
Valley area is sometimes characterized as being motivated by the desire to learn early about new technological developments, and this learning is apparently facilitated by geographical proximity. The result by Lichtenberg and van Pottelsberghe de la Potterie (1996) who find that a country's outward FDI gives access to foreign technology is consistent with that. The importance of return migration of foreign-trained students and engineers has also been emphasized in explaining the relatively fast acquisition of technological capability of countries like South Korea (Westphal et al., 1985), but we are not aware of more recent empirical work along these lines.

40 See, however, Globerman et al. (2000) and Lichtenberg and van Pottelsberghe de la Potterie (1996), who both analyze trade and FDI.
}

tion equipment. Because it is a priori plausible that international technology diffusion is most important in industries that account for a substantial part of all R\&D, some authors have restricted their analysis right from the start to such 'high-technology' industries (e.g. Bernstein and Mohnen, 1998). Other authors have tried to compare the magnitude of effects across industries. These studies fall primarily into the following two broad categories.

A first set of papers, including Coe et al. (1997) and Mayer (2001), is based on studies that explore the importance of international trade as a mechanism of international technology diffusion (see also $\mathrm{Xu}$ and Wang, 1999, discussed in Section 4). Using foreign knowledge stocks that are constructed as import-weighted sums of $R \& D$ in industrialized countries, Coe et al. (1997) find stronger and more robust evidence for north-south spillovers using machinery and equipment import data (SITC class 7) than employing either all-manufacturing or total import data. ${ }^{41}$ Mayer (2001) argues that this includes still many consumption and equipment goods that are unlikely to lead to much technology diffusion. His focus on machinery imports is confirmed in the sense that the machinery-imports based variable enters with a coefficient that is twice as large as in the corresponding regression using the variable based on all SITC 7 imports (Mayer, 2001, Tables 6 and 8). ${ }^{42}$

Another way to examine heterogeneity is to see whether the estimated spillover effects vary in magnitude across industries. Keller (2001c, 2002a) analyzes panels of twelve manufacturing industries. Eight of these twelve industries account for only about 20\% of all manufacturing $\mathrm{R} \& \mathrm{D}$, whereas-as mentioned earlier - the remaining four industries make up for the remaining $80 \%$. Keller shows separate regression results for the sample of low-R\&D industries, estimating that the elasticity of TFP with respect to R\&D is only about $70 \%$ of the average elasticity for all twelve industries. In his study of trade and technology diffusion in Latin America using the spillover regressions framework from above, Blyde (2001) finds stronger

\footnotetext{
${ }^{41}$ Connolly (1998) in her cross-country growth analysis of innovation and imitation uses the SITC class 7 data as well.

${ }^{42}$ For similar reasons, Keller (1997b, 2000) uses disaggregated data as well. He relates data on specialized machinery imports-at the three- and four-digit SITC level - to productivity at the twoand three-digit ISIC class level.
} 
effects from OECD imports than from Latin American imports. He attributes this result primarily to the fact that OECD imports have a higher embodied technology content than Latin American imports.

These results are consistent with international technology spillovers varying greatly in strength across different set of goods. Another literature has started to assess the importance of international technology diffusion from one set of products to another. In particular, some authors have suggested that advances in ICTs might have strong productivity effects in other industries, perhaps even abroad. Gera et al. (1999) estimates of technology spillovers from the US to Canada suggest that technology spillovers embodied in ICT imports from the US have about four times the effect on labor productivity in Canadian industries as spillovers embodied in non-ICT imports.

Keller (2002b) analysis provides an estimate of productivity effects from four different sources of $R \& D$ : domestic $R \& D$ as well as foreign $R \& D$, both in the same industry as well as in other industries. Using an input-output matrix to model inter-industry technology flows, his findings suggest that the importance of foreign R\&D outside the industry itself is as important for productivity as the foreign $R \& D$ within the industry. ${ }^{43}$

\section{Geographic localization of international technology diffusion}

It was noted earlier that income convergence depends on whether technology spillovers are local or global, with strong international diffusion favoring convergence and geographically localized diffusion making divergence more likely. Thus, a number of authors, including Jaffe et al. (1993), Irwin and Klenow (1994), Jaffe and Trajtenberg (1998), Eaton and Kortum (1999), and Branstetter (2001b), provide results on whether technology diffusion within a country is stronger than across countries. ${ }^{44}$

\footnotetext{
${ }^{43}$ See also the evidence on spillovers in technologically proximate fields in the section on FDI above.

${ }^{44}$ In addition to the geographic dimension of technology diffusion, one might also analyze its temporal and sectoral dimension. In particular, one might ask how long it takes until technology has diffused from a given country to another country. Such diffusion times might systematically vary with level of development and
}

Using patent citations as their measure of knowledge flows, Jaffe et al. (1993) compare the geographic location of patent citations with that of the cited patents in the United States. Their key finding is that US patents are significantly more often cited by other US patents than they are cited by foreign patents. Branstetter (2001b) uses R\&D and patenting data on US and Japanese firms to compute weighted R\&D spillover stocks analogous to Coe and Helpman (1995) bilateral import share weights. ${ }^{45}$ Branstetter finds that within-country spillovers are much stronger than between-country spillovers. The work on patenting and international technology diffusion by Eaton and Kortum (1999) and Jaffe and Trajtenberg (1998) supports this result as well.

However, Irwin and Klenow (1994) study of learning-by-doing spillovers in the semiconductor industry finds the opposite. ${ }^{46}$ These authors estimate that for eight vintages of semiconductors introduced between 1974 and 1992, the learning spillovers from one US firm to another US firm are not significantly stronger than those between an US firm and a foreign firm. The different results might be obtained because Irwin and Klenow's learning-by-doing spillovers, which are identified from the effects of cumulative production on market shares, are different from knowledge spillovers as measured in the other studies. ${ }^{47}$ It could also be due to the market structure of the semiconductor industry, which had only relatively few firms that were located primarily in the US and in Japan during this period.

In order to make further progress, it might therefore be necessary to study geographic effects in technol-

other covariates. Such an analysis will likely be complementary to studying the geographic dimension of technology diffusion at a given point in time, on which we focus here.

45 Patenting data by technological field allows Branstetter to compute weights that are increasing in the similarity of two firms' patenting activities; this captures the idea that $R \& D$ expenditures of another firm is more likely to generate spillovers, the closer the two firms are in technology space (see Jaffe, 1986).

${ }^{46}$ Learning-by-doing spillovers are most closely related to human capital models (e.g. Lucas, 1988, 1993), not to models of endogenous technological change. However, it is not clear that empirical analysis has been able to separate one from the other so far. We thus include the following discussion.

${ }^{47}$ In particular, the effects captured by Irwin and Klenow are much broader than the notion of knowledge flows as evidenced by patent citations. 
ogy diffusion beyond the basic "border effect". The most direct approach is to analyze international technology spillovers conditional on geographic distance and the location of countries relative to each other. By estimating whether there is geographic decay in the strength of technology spillovers, Keller (2001c, 2002a) has done this for OECD countries. For example, if geographic proximity matters for benefiting from international technology diffusion, then technology created in the US should have a stronger influence on productivity in Canada than in Germany; and the latter effect should in turn be stronger than the effect in Australia, ceteris paribus.

Keller (2002a) uses industry-level data from 14 OECD countries between 1970 and 1995. He relates productivity in nine mostly smaller OECD countries to $R \& D$ conducted in the G-5 countries, and allows for the possibility that the strength of the R\&D effects are conditional on a country's bilateral distance to the G-5 countries. He estimates a simple exponential decay function:

$$
\begin{aligned}
\ln \mathrm{TFP}_{c i t}= & \beta \ln \left(R_{c i t}+\gamma \sum_{h \neq c} R_{h i t} \mathrm{e}^{-\delta D_{c h}}\right) \\
& +\boldsymbol{\alpha}^{\prime} \boldsymbol{X}+\varepsilon_{c i t} .
\end{aligned}
$$

Here, $R_{h}$ is R\&D in the G-5 country $h$, and $D_{c h}$ is the geographic distance between countries $c$ and $h$. The vector $\boldsymbol{X}$ is a set of other variables that help to control for the effects of simultaneity. Of key interest in this framework is the parameter $\delta$ : for $\delta>0$, variation in productivity levels is best accounted for by giving a lower weight to $R \& D$ conducted in countries that are located relatively far away, whereas if $\delta=0$, then geographic distance and relative location do not matter. Keller (2002a) estimates $\delta$ to be positive, which is consistent with the geographic localization of international technology diffusion. ${ }^{48}$

What is the magnitude of this effect? The exponential specification allows to compute the 'half-life of technology' in terms of distance-the distance after which half of the technological knowledge that originates from a technology sending country has disappeared. Keller (2002a) estimates it to be only about

\footnotetext{
${ }^{48}$ See also Bottazzi and Peri (1999) analysis of geographic effects in the diffusion of technology among European regions.
}

$1200 \mathrm{~km}$. This corresponds to a very rapid geographic decay. If literally true, it implies that for instance Australia, with its remote geographic location relative to the G-5 countries, benefits extremely little from international technology diffusion. Instead of analyzing technology diffusion from the G-5 to mostly smaller OECD countries, Keller (2001c) studies technology diffusion among the G-7 countries, which account for about $90 \%$ of the world's R\&D spending. Using similar methods, he confirms the finding of localization of technology diffusion, estimating a half-life of technology between 800 and $1900 \mathrm{~km}$.

From an economic viewpoint, the finding that geographic distance matters is only the first step, of course. The question is, why does distance matter? At a prescriptive level, it is clearly impossible to design economic policies that "move Australia geographically closer to the G-5 countries", at least in a literal sense. Thus, it is important to see whether the geography effect can be related to the economic interactions across countries, including those discussed in Section 4.

Keller (2001c) considers the technology diffusion channels of imports, FDI, and communication. He introduces variables that measure the strength of each of the respective bilateral channels in analogy to geographic distance in the equation on p. 38. According to his analysis, each channel individually has a positive effect on international technology diffusion. When the channels of imports, FDI, and communication are considered together with distance, Keller does not estimate a geographic localization effect anymore. This suggests that a substantial portion of the distance effect in technology diffusion, and may be all of it, can be accounted for by differences in imports, FDI, and communication links across countries. ${ }^{49}$

\section{Changes in the scope and strength of diffusion over time}

Today's level of economic integration in the world is high by historical standards (e.g. Feenstra, 1995).

\footnotetext{
${ }^{49}$ See also Sjöholm (1996) who finds that bilateral geographic distance between Sweden and other countries has no robust effect on the number of citations in Swedish patent applications, once differences in bilateral international trade have been controlled for.
} 
International trade has been growing faster than income, and transport costs for goods have been falling. Multinational activity has been growing faster than trade, spurred in part by the development of new communication technologies. And the Internet is considered by many to be the primary symbol of a globally integrated world.

What does this mean for technological diffusion? Is there now a common pool of global technology, and distance is, as some have suggested, "dead"? The recent papers by Keller (2001c, 2002a) provide some initial evidence on this. He estimates whether the parameter that captures localization in his specification has changed over time. Keller finds that the absolute value of the distance parameter has fallen substantially between the mid-1970s and the 1990s. This is consistent with a strong decline over time in the degree to which technology is geographically localized. It constitutes some initial quantitative evidence that technological knowledge has become less country-specific recently.

\section{Major determinants of successful international technology diffusion}

We have noted earlier that technology diffusion in form of spillovers means that it involves externalities-economic relations that are not covered by market transactions. As such, spillovers are related to the much larger topic of market and institutional failures in economic development in general. This literature is vast, and we will not attempt to provide a comprehensive survey. ${ }^{50}$ In the specific case of technology transfer through spillovers though, there are big differences in the degree of success that countries have in benefiting from foreign technology. Another strand of the literature has therefore asked what the major determinants of successful technology diffusion from abroad are. Differences in the degree of success of technology adoption could mean that income variation in the world is either increasing (divergence) or decreasing (convergence) over time. There are some preliminary findings suggesting that between the years 1983 and 1995, technology diffusion from the G-7 countries had stronger effects on growth in

\footnotetext{
${ }^{50}$ For this, see Handbook of Development Economics (1995).
}

the relatively rich than in the poorer countries (Keller, 2001b). This might in part explain the trend towards income divergence for the world as a whole during this period.

Two determinants of successful technology diffusion that have been emphasized are human capital (Nelson and Phelps, 1966) and R\&D (Cohen and Levinthal, 1989). Both are associated with the notion of absorptive capacity, the idea that a firm or country needs to have a certain type of skill in order to be able to successfully adopt foreign technological knowledge. ${ }^{51}$ This can be, first of all, in form of science and engineering human capital. It can also be in form of another factor, first emphasized by Cohen and Levinthal (1989): a firm might need to invest itself into R\&D. These authors argue that this is critical to enabling the firm to understand and evaluate new technological trends and innovations, which is a necessary condition for successful technology adoption.

Along these lines, Eaton and Kortum (1996) find that inward technology diffusion as measured by international patenting is increasing in the level of a country's human capital. Xu (2000) provides evidence suggesting that the reason why relatively rich countries benefit from hosting US multinational subsidiaries, while poorer countries do not as much has to do with a threshold level of human capital in the host country. Caselli and John Coleman (2001) use data on imports of office, computing, and accounting machinery as a measure of inward technology diffusion, arguing that many countries do not have a domestic computer industry, so that computer technology comes necessarily from abroad. They find that computer imports are positively correlated with measures of human capital, which is consistent with the results by Eaton and Kortum (1996) and Xu (2000). In these three papers, the measures of human capital have only a quantity dimension, the average number of years of schooling or school enrollment in the population. Hanushek and Kimko (2000) have recently argued that the quality dimension of human capital is at least as important. Their results using standardized science and engineering test scores for around thirty countries seems to bear this out. I expect that as test score data becomes available for a larger set of less developed countries,

\footnotetext{
${ }^{51}$ Keller (1996) presents a model of absorptive capacity in a growth context.
} 
it will be able to show that science and engineering skills are important in facilitating technology diffusion.

Griffith et al. (2000a,b) have recently emphasized the importance of indigenous $R \& D$ to facilitate technology diffusion from abroad (see also Kinoshita, 2000, discussed in Section 4). Griffith et al. (2000a) use industry-level data from 12 OECD countries for the years 1974 to 1990 to study what are the main determinants of productivity dynamics in this sample. The authors construct a productivity gap measure, defined as TFP relative to TFP in the leader country; this is a measure of the potential for productivity catch-up. Griffith et al. (2000a) find that subsequent TFP growth is negatively related to the productivity gap, which is consistent with productivity convergence. If the productivity gap variable is interacted with $\mathrm{R} \& \mathrm{D}$, the authors estimate a strong negative coefficient. This is consistent with absorptive capacity being empirically important, because it says that catch-up is particularly rapid if there are substantial R\&D investments in low-productivity industries. $^{52}$

We now turn to a summary and some concluding remarks.

\section{Summary and implications}

It is evident from our discussion that the literature that empirically quantifies the effects of international technology diffusion is a fairly recent one. While we know today much more than we did merely a couple of years ago, there are only few results that are solidly established at this point. To date, different strands of research on a particular topic give seemingly or actually conflicting answers; some of the results that have been reviewed above might still be overturned, and many important topics have not been considered yet at all. Nevertheless, we will try to draw some general lessons from what we know right now.

In general, there is a substantial amount of evidence that underlines the importance of international technology diffusion for growth and development. Once authors allow for technology to be either of domes-

\footnotetext{
52 These authors also find that interacting human capital with the productivity gap leads to a smaller effect.
}

tic or international origin, studies do find international sources to be important. ${ }^{53}$ The evidence so far suggests that the relative importance of foreign sources for productivity growth is decreasing in size and level of development. It is probably no exaggeration to believe that the relative importance of foreign technology in most less developed countries is at least $90 \%$, and probably higher. At the same time, there is no indication that international learning is inevitable or automatic, merely a function of what Gerschenkron (1962) has called economic backwardness. Instead, differential learning effects seem to be in part explained by the extent and the way in which firms of different countries engage in international economic activities. What is the evidence on this so far?

As we previously argued, foreign technology spillovers can be of two different types: active spillovers and passive spillovers. Active spillovers involve the direct process of learning about foreign technological knowledge, which can be either in codified or in non-codified form. Passive spillovers are resulting from employing intermediate goods that embody technological knowledge invented abroad. Active spillovers involve domestic agents learning about foreign knowledge to the extent that they can use, modify, and improve upon the technology. Passive spillovers do not lead to those abilities, implying that an effective technology gap remains. Because passive spillovers are associated with intermediate goods, the patterns of passive spillovers are likely following international transactions that involve such goods. Active spillovers are not associated with technology embodied in goods, but this does not mean that the patterns of active spillovers are arbitrary, or that they are universal. In particular, the importance of non-codified and tacit elements of technology means

\footnotetext{
53 Does this matter relative to analyses that emphasize differences in the endowment with quality-adjusted capital (Mankiw, 1995) or in policies towards technology adoption (Parente and Prescott, 2000)? It is true that at a given point in time, the process of international technology diffusion must manifest itself in cross-country technology differences, which translate into income differences. That all approaches will in the end lead to some statistics in the national income accounts is not surprising - after all, each of them tries to explain GDP. The important questions are rather: which framework is helpful for thinking about productivity growth, and which is useful to guide economic policy towards raising productivity growth.
} 
in practice that the acquisition of active spillovers often involves face-to-face contacts.

There is evidence showing that the degree of commoditization of goods and services is increasing, which is in part related to the development of so-called Internationally Integrated Production Systems. If technology can be increasingly commoditized as well, to codified and embodied knowledge, this could mean that face-to-face contacts become less important. Similarly, it would mean that passive spillovers might gain in relative importance at the expense of active spillovers. This could also mean an increasing concentration of fundamental technological expertise (of the active type) in a small number of countries of the world.

International trade has been a suggested as a major channel for technology diffusion early on. The refinements of R\&D spillover regressions in response to the papers by Coe and Helpman (1995) and Keller (1998) now point to a robust link between imports and technology diffusion. This evidence is strengthened by results from relating patent citations to import patterns as well as by estimating general equilibrium models of embodied technology diffusion. While the evidence using micro-data is much weaker, especially on learning effects from exporting, my sense is that at least qualitatively, trade facilitates international technology diffusion. Some results, for instance by Lumenga-Neso et al. (2001), indicate that there might be much to be learned from future work that studies the full dynamics of trade and technology diffusion instead of only the long-run stationary relationships.

On FDI as a mechanism of technology diffusion, the results so far are mixed. The result that FDI does not necessarily lead to strong positive spillovers is a sensible one. After all, a cornerstone of the theory of FDI says that firms choose to operate through a fully-owned subsidiary instead of through joint ventures or technology licensing because FDI helps to keep the private return to technology investments internal to the firm-that is, no leaking out of knowledge.

In general, the evidence for positive effects from inward FDI is stronger for more developed than for less developed countries. This might have to do with the fact that outsourcing of relatively low-skill activities is more likely for north-south FDI than for north-north FDI (e.g. Hanson et al., 2001). The former could have a lower learning potential than the latter, not necessarily because the activities are different as such, but because they are integrated with the host country economy to different degrees (in terms of backward and forward linkages). ${ }^{54}$ At any rate, the fact that the only study of those discussed above finding positive effects from inward FDI in a non-OECD country is one where firm-level data on $R \& D$ is availableKinoshita (2000)—suggests that local effort in adopting advanced foreign technology is very important.

Other mechanisms such as person-to-person communication have in our view not been analyzed to a sufficient degree yet. In part, this seems to have to do with a paucity of relevant data. This channel is also difficult to separate from trade and FDI, because the ease of communication is affecting the likelihood of trade relations, for example. To some extent, the relatively large contribution of trade and the smaller contribution of communication estimated in Keller (2001c) might simply reflect that trade is a more proximate correlate of international technology diffusion than communication is.

The literature on technology spillovers has moved increasingly away from single-channel analyses to multiple-channel analyses, or at least to work that simultaneously controls for overall (not-furtherspecified-) spillovers. To analyze multiple-channels especially in the context of a fully-specified general equilibrium model is not easy, but the returns from doing this seem to be high.

There are a number of results suggesting that the strength of technology diffusion across different sets of products varies: for certain types of high-tech products, international technology diffusion could easily be two or three times as strong as for the average manufacturing good, ceteris paribus. However, it is also true that price deflators for R\&D-intensive products are, due to fast-rising product quality, particularly hard to calculate. While it is plausible that active and passive spillovers associated with high-tech products are larger than those associated with lower-tech products, a part of the estimated difference might be spurious.

The question to what extent foreign technology diffuses throughout the domestic economy, or affects

\footnotetext{
54 The processing plants along the US-Mexican border (maquiladoras) might be a good example of FDI with relatively few backward and forward linkages.
} 
only a small segment of it is a subject that deserves further analysis. As the recent debate on whether advances in ICTs have raised the structural rate of growth in the US and elsewhere has begun to illustrate, the optimistic view about future productivity growth very much depends on economy-wide diffusion. The result that there are FDI spillovers in technologically proximate areas-outside of the narrowly-defined FDI industry itself - by Girma and Wakelin (2001) and Haskel et al. (2001) is interesting in this context.

Work on the level of geographic localization of technology diffusion has begun to shed light on whether technology diffusion is a force towards convergence or divergence. It would be useful to extend this analysis to a broad set of countries, which would allow to forecast what will happen to the world's distribution of income. The same is true for the result by Keller (2001c, 2002a) that technology has become less localized. It is important to find out whether that has happened only among OECD countries, or also in a broader set of countries: has technology become increasingly global, or merely more common among the relatively rich countries?

We also know very little right now about what are the primary causes that have led to this lower degree of knowledge localization among OECD countries. Learning more about these causes is important for thinking about what kind of policies might be effective in fostering the diffusion of technology from abroad.

Other important issues include the following. First, empirical studies of international technology diffusion provide to some extent different results because of conceptual and measurement differences. One important issue is how narrow or broad the concept of knowledge diffusion is. Patent citations are the narrowest measure that has been used, which is followed by patents or patent applications per se. A broader notion of technology diffusion is implicitly utilized by studies that infer international technology diffusion from the relationship between foreign $R \& D$ and productivity. The least narrow notion of technology spillovers is implied when some measure of international economic activity is related to productivity (e.g. the share of foreign-owned employment in total employment in much of the work on FDI spillovers).

The best measure of spillovers in the sense of an externality is probably a patent citation. All other measures might pick up also market-based technology transactions (such as royalty payments and licensing fees) and, probably more importantly, the outcome of changes in the competitive position of firms. These effects are not externalities, and they might have different welfare implications. However, a well-known problem of using patent statistics-both applications and citations-is that technological knowledge is not all patented (Griliches, 1990 provides a broader discussion). This could be because applying for a patent, or citing another patent, is a strategic decision of the firm. Even if this is not an issue, as long as a large part of knowledge is tacit, patent statistics will necessarily miss that part, because codification is necessary for patenting to occur. ${ }^{55}$

Thus, while some approaches to identify technology spillovers capture more than the pure externality effect, patent statistics might capture less than what we are interested in. Because a clearly dominating measure to identify technology diffusion is not available, there are good reasons for applying different approaches, as long as the relative advantages and disadvantages are recognized.

Second, a promising development for future empirical work on international technology diffusion is the increasing availability of large micro (firm or plant) level data sets. At times, there are sometimes exaggerated expectations. Micro-level data allow avoiding composition and aggregation biases that are often present in industry- and aggregate-level analysis. Other issues seem to be becoming even more pressing at the firm-level, such as the unavailability of price deflators. And to interpret a cross-sectional correlation of foreign ownership and productivity as evidence for FDI spillovers would be just inappropriate at the firm-level as it is at a more aggregate-level. As the studies discussed above indicate, however, micro-level data can help to take a major step forward. The biggest contribution of micro-level data sets comes probably from a better estimation of micro behavior, as the data records the outcome of economic decisions right

\footnotetext{
55 The inclusion of patent citations is at times imposed by the patent examiner, which probably reduces the usefulness of patent citations as a measure of knowledge flows. It is also worth keeping in mind that the number of patent applications differs across countries because the propensity to patent seems to differ across countries. For example, Eaton and Kortum (1996) scale down the number of Japanese patents by a factor of 4.9 for this reason, an approach that is widely used in the literature. The value of 4.9 is based on a 1992 working paper by Okada.
} 
at the decision-taking level. Empirical micro studies of technology diffusion that reach their full potential involve probably modeling the micro behavior as well.

Third, the evidence reviewed above indicates that micro-level studies paint often a more pessimistic picture on the strength of learning externalities through international economic activity than industry-level or aggregate studies do. This could be because the former avoid certain biases (see above); it might also have to do with the fact that data on the learning effort of host country firms has typically not been available. A third reason could be that micro-level studies so far are not based on a framework that explicitly allows for learning and spillover externalities between firms. That is, so far the micro evidence is based on 'no-externality' models. Future empirical work will hopefully employ models where the presumed learning effects from international economic activity exist as a matter of theory. At the same time, the empirical analysis should avoid picking up spurious effects.

What are the policy implications of this literature? The evidence is not strong enough yet to provide support for specific policy measures, such as a particular subsidy to a multinational enterprise for locating in a country. This would require more agreement on quantitative effects than there is right now. At this point, the results suggest that the international dimension of technological change is of key importance for most countries. In this situation, a closed-off international economic regime must have detrimental welfare consequences for a country.

There is also evidence that the relative importance of the international technology diffusion has been increasing with the level of economic integration in the world. This suggests that the performance advantage of outward-oriented economies over inward-oriented economies will be higher in the future than it is today. What if future research were to establish that international technology diffusion raises productivity more in advanced than in less developed countries? The implication for less developed countries would not be that a turn towards autarky is beneficial-on the contrary, given the evidence on positive productivity effects from international technology diffusion. Rather, if the benefits from operating in an international economic environment differ across countries, this suggests to investigate further the major reasons for this-what works, and why?

While there is no consensus yet on the exact magnitude of spillover benefits, it is clear that well-functioning markets and an undistorted tradeand foreign-investment regime are conducive to these learning effects. However, the evidence suggests that the latter are quite difficult to pin down. For one, it does not seem to be primarily a matter of simply specializing on high-tech goods. Rather, the goods characteristics are only part of what is important. India, for example, aimed at producing relatively advanced products during its era of import substitution policy, but their quality was low compared to international standards. In contrast, south-east Asian countries such as Hong Kong and South Korea were initially specializing in relatively low-tech products, and moved successfully into the range of higher-tech products only gradually.

Technology diffusion is by no means automatic. Technological knowledge spillovers appear to be resulting from a deliberate commitment to learning and matching international performance standards through ongoing interaction with foreigners. Local efforts are clearly necessary for successful technology adoption as well. For that, technological capability to acquire, assimilate, or create technology, is needed in a country to successfully develop economically. ${ }^{56}$ This is particularly important for developing countries, given that they purchase or otherwise acquire most of their technology from abroad. Developing technological capability requires appropriate policies that help building the necessary institutions and provide the correct incentives. This framework will also contribute to efficient domestic technology transfers, for instance between different industries. At the same time, the ongoing interaction with foreign firms and consumers seems to be a process of knowledge discovery for firms that cannot be had from interacting only with other domestic firms. To model as well as empirically capture these in a convincing way continues to be a challenge.

\footnotetext{
56 This is consistent with the emphasis of evolutionary theories on the importance of networks and links between diverse institutions as a major factor behind the innovative capacity of a nation (cf. Nelson, 1993).
} 


\section{Acknowledgements}

We would like to thank Sourafel Girma for providing some regression results. We have also benefited from conversations with Bob Baldwin and Elhanan Helpman, as well as from comments by Peter Klenow, Sam Kortum, Jörg Mayer, and Maurice Schiff. This paper draws heavily on Keller (2001a).

\section{References}

Adams, J., Jaffe, A., 1996. Bounding the effects of R\&D: an investigation using matched establishment-firm data. RAND Journal of Economics 27, 700-721.

Aghion, P., Howitt, P., 1992. A model of growth through creative destruction. Econometrica 60, 323-351.

Aghion, P., Howitt, P., 1998. Endogenous Growth Theory. MIT Press, Cambridge, MA.

Aitken, B., Harrison, A., 1999. Do domestic firms benefit from foreign direct investment? Evidence from Venezuela. American Economic Review 89, 605-618.

Arrow, K., 1969. Classificatory notes on the production and transmission of technological knowledge. American Economic Review Paper and Proceedings 59, 29-35.

Baldwin, R., Braconier, H., Forslid, R., 1999. Multinationals, endogenous growth and technological spillovers: theory and evidence. CEPR Discussion Paper No. 2155.

Behrman, J., Srinivasan, T.N. (Eds.), Handbook of Development Economics, vols. 3A and 3B. Elsevier, Amsterdam.

Bernard, A., Jensen, B., 1999. Exceptional exporter performance: cause, effect or both? Journal of International Economics 47, $1-25$.

Bernstein, J., Mohnen, P., 1998. International R\&D spillovers between US and Japanese R\&D intensive sectors. Journal of International Economics 44, 315-338.

Blyde, J., 2001. Trade and technology diffusion in Latin America. Inter-American Development Bank Working Paper, Washington, DC.

Blomström, M., Kokko, A., 1998. Multinational corporations and spillovers. Journal of Economic Surveys 12, 247-277.

Bottazzi, L., Peri, G., 1999. Innovation, demand, and knowledge spillovers: theory and evidence from european regions. CEPR Working Paper No. 2279, London, UK, October.

Branstetter, L., 2001a. Is foreign direct investment a channel of knowledge spillovers? Evidence from Japan's FDI in the United States, NBER Working Paper No. 8015.

Branstetter, L., 2001b. Are knowledge spillovers international or intranational in scope? Microeconometric evidence from the US and Japan. Journal of International Economics 53, 53-79.

Carr, D., Markusen, J., Maskus, K., 2001. Estimating the knowledge-driven model of the multinational enterprise. American Economic Review 91, 693-708.

Caselli, F., John Coleman II, W., 2001. Cross-country technology diffusion: the case of computers. American Economic Review 91, 328-335.
Cimoli, M., 2001. Networks, market structures and economic shocks, the structural changes of innovation systems in Latin America. In: Proceedings of the Paper Presented at Seminar on Redes Peroductivas e Institucionales en America Latina, Buenos Aires, 9-12 April 2001.

Cimoli, M., Katz, J., 2001. Structure reforms, technology gaps and economics development: a Latin American perspective. In: Proceedings of the Paper Presented at DRUID-Nelson and Winter Conference, Aalborg, 12-15 June 2001.

Clerides, S., Lach, S., Tybout, J., 1998. Is learning by exporting important? Micro-dynamic evidence from Colombia, Mexico, and Morocco. Quarterly Journal of Economics 113, 903-948.

Coe, D.T., Helpman, E., 1995. International R\&D spillovers. European Economic Review 39, 859-887.

Coe, D., Hoffmaister A., 1999. Are there international R\&D spillovers among randomly matched trade partners? A response to Keller, IMF Working Paper No. 99/18, February.

Coe, D., Helpman, E., Hoffmaister, A., 1997. North-south spillovers. Economic Journal 107, 134-149.

Cohen, W., Levinthal, D., 1989. Innovation and learning: the two faces of R\&D. Economic Journal 99, 569-596.

Connolly, M., 1998. The dual nature of trade: measuring its impact on imitation and growth. Working Paper, Duke University, December.

Dahlman, C.J., Ross-Larson, B., Westphal, L.E., 1987. Managing technological development: lessons from the newly industrializing countries. World Development 15, 759-775.

David, P., 1992. Knowledge, property, and the systems dynamics of technological change. In: Summers, L., Shah, A. (Eds.), Proceedings of the World Bank Annual Conference on Development Economics 1992, pp. 215-248.

David, P., Olsen, T., 1992. Technology adoption, learning spillovers and the optimal duration of patent based monopolies. International Journal of Industrial Organization 10, 517-544.

Dornbusch, R., Fischer, S., Samuelson, P., 1977. Comparative advantage, trade, and payments in a Ricardian model with a continuum of goods. American Economic Review 67, 823-839.

Dosi, G., Nelson, R., 1994. An introduction to evolutionary theories in economics. Journal of Evolutionary Economics 4 (3), 15-72.

Easterly, W., Levine, R., 2001. It's not factor accumulation: stylized facts and growth models. In: Paper Presented at the Conference on What Have We Learned from a Decade of Empirical Research on Growth? 26 February 2001, The World Bank. World Bank Economic Review 15, 177-219.

Eaton, J., Kortum, S., 1996. Trade in ideas: patenting and productivity in the OECD. Journal of International Economics 40, 251-278.

Eaton, J., Kortum, S., 1997. Engines of growth: domestic and foreign sources of innovation. Japan and the World Economy 9, 235-259.

Eaton, J., Kortum, S., 1999. International patenting and technology diffusion: theory and measurement. International Economic Review 40, 537-570.

Eaton, J., Kortum, S., 2001a. Trade in capital goods. European Economic Review 45 (7), 1195-1235.

Eaton, J., Kortum, S., 2001b. Technology, geography, and trade. Econometrica (in press). 
Eaton, J., Gutierrez, E., Kortum, S., 1998. European technology policy. Economic Policy 27, 405-438.

Economist, 2000. Untangling E-conomics. A survey of the new economy. The Economist, 23 September.

Ethier, W., 1982. National and international returns to scale. American Economic Review.

Evenson, R., Westphal, L., 1995. Technology change and technology strategy. In: Behrman, J., Srinivasan, T.N. (Eds.), Handbook of Development Economics, vol. 3A. North-Holland, Amsterdam.

Fagerberg, J., 1994. Technology and international differences in growth rates. Journal of Economic Literature 32 (September), $1147-1175$.

Feenstra, R., 1995. Integration of trade and disintegration of production in the global economy. Journal of Economic Perspectives 1998 (Fall), 31-50.

Feenstra, R., Markusen, J., Zeile, W., 1994. Accounting for growth with new inputs. International Economic Review 35, 429-447.

Feldman, M., Lichtenberg, F., 1997. The impact and organization of publicly-funded research and development in the European Community. NBER Working Paper No. 6040.

Gera, S., Gu, W., Lee, F., 1999. Information technology and productivity growth: an empirical analysis for Canada and the United States. Canadian Journal of Economics 32, 384-407.

Geroski, P.A., 2000. Models of technology diffusion. Research Policy 29, 603-625.

Gerschenkron, A., 1962. Economic Backwardness in Historical Perspective. Harvard University Press, Cambridge, MA.

Girma, S., Wakelin, K., 2001. Regional underdevelopment: is FDI the solution? A semi-parametric analysis. GEP Research Paper No. 2001/11, University of Nottingham, UK.

Globerman, S., Kokko, A., Sjöholm, F., 2000. International technology diffusion: evidence from Swedish patent data. Kyklos 53, 17-38.

Griffith, R., Redding, S., Van Reenen, J., 2000a. Mapping two faces of R\&D: productivity growth in a panel of OECD industries. Mimeo, London School of Economics, November.

Griffith, R., Redding, S., Van Reenen, J., 2000b. R\&D and absorptive capacity: from theory to data. Mimeo, London School of Economics, November.

Griliches, Z., 1979. Issues in assessing the contribution of research and development to productivity growth. Bell Journal of Economics 10, 92-116.

Griliches, Z., 1990. Patent statistics as economic indicators: a survey. Journal of Economic Literature 28, 1661-1707.

Griliches, Z., 1995. R\&D and productivity: econometric results and measurement issues. In: Stoneman, P. (Ed.), Handbook of the Economics of Innovation and Technological Change. Blackwell, Oxford, pp. 52-89.

Grossman, G., Helpman, E., 1991. Innovation and Growth in the World Economy. MIT Press, Cambridge, MA.

Grossman, G., Helpman, E., 1995. Technology and trade. In: Grossman, G., Rogoff, K. (Eds.), Handbook of International Economics, vol. 3. North-Holland, Amsterdam.

Hall, R., Jones, C., 1999. Why do some countries produce so much more output per worker than others? Quarterly Journal of Economics 114, 83-116.
Hanson, G., Mataloni, R., Slaughter, M., 2001. Expansion strategies of US multinational firms. NBER Working Paper No. 8433.

Hanushek, E., Kimko, D., 2000. Schooling, labor-force quality, and the growth of nations. American Economic Review, December.

Haskel, J., Pereira, S., Slaughter, M., 2001. Does inward foreign direct investment boost the productivity of domestic firms? In: Paper Presented at the NBER Summer Institute, August.

Howitt, P., 2000. Endogenous growth and cross-country income differences. American Economic Review.

Hulten, C.R., 2001. Total factor productivity. In: Hulten, C.R., Dean, E.R., Harper, M.J. (Eds.), New Developments in Productivity Analysis. The University of Chicago Press, Chicago and London, pp. 1-53.

Griliches, Z., 1995. R\&D and productivity: econometric results and measurement issues. In: Stoneman, P. (Ed.), Handbook of the Economics of Innovation and Technological Change. Blackwell, Oxford, pp. 52-89.

Irwin, D., Klenow, P., 1994. Learning spillovers in the semiconductor industry. Journal of Political Economy.

Jaffe, A., 1986. Technological opportunity and spillover of R\&D: evidence from firm's patents, profits, and market value. American Economic Review 76, 984-1001.

Jaffe, A., Trajtenberg, M., 1996. Modelling the flows of knowledge spillovers. NBER Working Paper, Cambridge, MA.

Jaffe, A., Trajtenberg, M., 1998. International knowledge flows: evidence from patent citations. NBER Working Paper No. 6507, April.

Jaffe, A., Trajtenberg, M., Henderson, R., 1993. Geographic localization of knowledge spillovers as evidenced by patent citations. Quarterly Journal of Economics 108, 577-598.

Katz, J., 2000. Reformas estructurales, productividad y Conducta Tecnologica, Fondo de Cultura YCEPAL, Santiago (English edition: Structural Reforms, Productivity and Technological Change in Latin America, ECLAC, Santiago, Chile).

Keller, W., 1996. Absorptive capacity: on the creation and acquisition of technology in development. Journal of Development Economics 49, 199-227.

Keller, W., 1997a. Technology flows between industries: identification and productivity effects. Economic Systems Research 9, 213-220.

Keller, W., 1997b. How trade patterns and technology flows affect productivity growth. World Bank Policy Research Working Paper No. 1831, September.

Keller, W., 1998. Are international R\&D spillovers trade related? Analyzing spillovers among randomly matched trade partners. European Economic Review 42, 1469-1481.

Keller, W., 2000. Do trade patterns and technology flows affect productivity growth? World Bank Economic Review 14, 17-47.

Keller, W., 2001a. International technology diffusion. NBER Working Paper No. 8573, October.

Keller, W., 2001b. Do the new information and trade links of the 1990s lead to convergence or divergence? In: Paper Presented at the NBER Summer Institute, Cambridge, MA, August.

Keller, W., 2001c. Knowledge spillovers at the world's technology frontier. CEPR Working Paper No. 2815, May.

Keller, W., 2002a. Geographic localization of international technology diffusion. American Economic Review 92, 120-142. 
Keller, W., 2002b. Trade and the transmission of technology. Journal of Economic Growth 7, 5-24.

Kinoshita, Y., 2000. R\&D and technology spillover via FDI: innovation and absorptive capacity. Mimeo, William Davidson Institute at the University of Michigan Business School, October.

Klenow, P., 2001. Comments on the Paper by Easterly and Levine at the Conference on What Have We Learned from a Decade of Empirical Research on Growth? 26 February 2001, The World Bank. World Bank Economic Review.

Klenow, P., Rodriguez-Clare, A., 1997. The neoclassical revival in growth economics: has it gone too far? NBER Macroeconomics Annual 12, 73-102.

Kraay, A., I. Soloaga, J. Tybout, 2001. Product quality, productive efficiency, and international technology diffusion: evidence from plant-level panel data. In: Paper Presented at the NBER Summer Institute, July.

Leamer, E., Levinsohn, J., 1995. International trade theory: the evidence. In: Grossman, G. Rogoff, K. (Eds.), Handbook of International Economics, vol. 3. Elsevier, Amsterdam.

Lichtenberg, F., van Pottelsberghe de la Potterie, B., 1996. International R\&D spillovers: a re-examination. NBER Working Paper No. 5688.

Lucas, R., 1988. On the mechanics of economic development. Journal of Monetary Economics 22, 3-42.

Lucas, R., 1993. Making a miracle. Econometrica 61, 251-272.

Lumenga-Neso, O., Olarreaga, M. Schiff, M., 2001. On 'indirect' trade-related R\&D spillovers. Mimeo, The World Bank, February.

Lundvall, B.-Å. (Ed.), 1992. National Systems of Innovation: Towards a Theory of Innovation and Interactive Learning. Pinter, London.

Mankiw, N.G., 1995. The growth of nations. Brookings Papers on Economic Activity 1, 275-310.

McKinsey, 2000. Why the Japanese economy is not growing: micro-barriers to productivity growth. McKinsey Global Institute, Washington, DC, July.

Mayer, J., 2001. Technology diffusion, human capital and economic growth in developing countries. UNCTAD Discussion Paper No. 154, Geneva, June.

Mohnen, P., 1992. The Relationship between R\&D and Productivity Growth in Canada and other Industrialized Countries. Minister of Supply and Services Canada, Ottawa.

Mohnen, P., 2001. International R\&D spillovers and economic growth. In: Pohjola, M. (Ed.), Information Technology, Productivity, and Economic Growth: International Evidence, UNU/WIDER and Sitra. Oxford University Press, Oxford.

Nadiri, M.I., Kim, S., 1996. International R\&D spillovers, trade and productivity in major OECD countries. NBER Working Paper No. 5801.

Nelson, R. (Ed.), 1993. National Innovation Systems: A Comparative Analysis. Oxford University Press, Oxford, 1993.

Nelson, R., Phelps, E., 1966. Investment in humans, technological diffusion and economic growth. American Economic Review $56,69-75$.

Nelson, R., Winter, S., 1982. An Evolutionary Theory of Economic Change. Belknap Press, Cambridge.
Nelson, R., Winter, S., 2002. Evolutionary theorizing in economics. The Journal of Economic Perspectives 16, 23-46.

Olley, S., Pakes, A., 1996. The dynamics of productivity in the telecommunications equipment industry. Econometrica 64, 1263-1297.

Olson, M., 1982. The Rise and Fall of Nations. Yale University Press, New Haven, CT.

Parente, S., Prescott, E., 2000. Barriers to Riches. MIT Press, Cambridge, MA.

Park, W., 1995. International R\&D spillovers and OECD economic growth. Economic Inquiry 23, 571-591.

Polanyi, M., 1958. Personal Knowledge Towards a Post-Critical Philosophy. University of Chicago Press, Chicago, IL.

Prescott, E.C., 1998. Needed: a theory of total factor productivity. International Economic Review 39, 525-551.

Quah, D., 2001a. Technology Dissemination and economic growth. Working Paper, LSE, April.

Quah, D., 2001b. Demand-driven knowledge clusters in a weightless economy, LSE, April.

Rhee, Y., Ross-Larson, B., Pursell, G., 1984. Korea's Competitive Edge: Managing the Entry into World Markets. Johns Hopkins University Press for the World Bank, Baltimore, MD.

Rivera-Batiz, L., Romer, P., 1991. Economic integration and endogenous growth. Quarterly Journal of Economics 106, 531555.

Romer, P., 1990. Endogenous technological change. Journal of Political Economy 98, S71-S102.

Romer, P., 1992. Two strategies for economic development: using ideas and producing ideas. In: Summers, L., Shah, A. (Eds.), Proceedings of the World Bank Annual Conference on Development Economics 1992, pp. 63-91.

Rosenberg, N., 1976. On technological expectations. Economic Journal 86, 223-235.

Scherer, F., 1984. Using linked patent and R\&D data to measure interindustry technology flows. In: Griliches, Z. (Ed.), R\&D, Patents, and Productivity. The University of Chicago for NBER, pp. 417-461.

Segerstrom, P., Anant, T., Dinopoulos, E., 1990. A Schumpeterian model of the product life cycle. American Economic Review 80, 1077-1092.

Sjöholm, F., 1996. International transfer of knowledge: the role of international trade and geographic proximity. Weltwirtschaftliches Archives 132, 97-115.

Solow, R., 1957. Technical change and the aggregate production function. Review of Economics and Statistics.

Solow, R., 2001. Applying growth theory across countries. In: Comments Presented at the Conference on What Have We Learned from a Decade of Empirical Research on Growth? 26 February 2001, The World Bank. World Bank Economic Review.

Stoneman, P., Kwon, M.-J., 1994. The diffusion of multiple process technologies. Economic Journal 104, 420-431.

Teece, D., 1977. Technology transfer by multinational firms: the resource cost of transferring technological know-how. Economic Journal 87, 242-261.

Tybout, J., 2000. Manufacturing firms in developing countries: how well do they do, and why? Journal of Economic Literature 38 (March), 11-44. 
Tybout, J., 2001. Plant- and firm-level evidence on "new" trade theories. NBER Working Paper No. 8418, August.

Vernon, R., 1966. International investment and international trade in the product cycle. Quarterly Journal of Economics 80, 190227.

von Hippel, E., 1994. Sticky information and the locus of problem solving: implications for innovation. Management Science 40, 429-439.

Westphal, L., Kim, L., Dahlman, C., 1985. Reflections on the Republic of Korea's acquisition of technological capability. In:
Rosenberg, N., Frischtak, C. (Eds.), International Technology Transfer. Praeger, New York, pp. 167-227.

Witt, U., 1993. Introduction. In: Witt, U. (Ed.), Evolutionary Economics. Edward Elgar, Cheltenham, pp. xii-xxvii.

Xu, B., 2000. Journal of Development Economics 62, 477-493.

Xu, B., Wang, J., 1999. Capital goods trade and R\&D spillovers in the OECD. Canadian Journal of Economics 32, $1258-1274$.

Young, A., 1991. Learning-by-doing and the dynamic effects of international trade. Quarterly Journal of Economics. 